\title{
Formation of Preschool Management Model for Improving the Quality of Preschool in Sarawak
}

\author{
Thian Vui Shau \\ Sultan Idris Education University, Malaysia
}

\begin{abstract}
This study aims to produce a new model for improving the quality of preschool education in Malaysia. To explore issues of education quality, structural equation modeling (SEM) was used to analyze the relationship between theory and model constructs according to the Preschool Management Model (PMM). In this study, the researcher is interested to analyse the causal effect of headmasters' instructional leadership on effective teaching among preschools and subsequently test the hypothesis in order to prove its significance. In addition, the study also establish the correlation of four mediators between headmasters' instructional leadership and effective teaching. This study involved collecting data for the survey questionnaires. The models were analyzed and tested using multivariate analysis technique known as Structural Equation Modeling (SEM) for goodness of fit by using AMOS software. The findings of this study highlight that parental involvement in preschool education, teacher professional development and preschool development plan are full mediator. Because of this, headmasters should strive to implement TQM practices by mandating the quality of the education system.
\end{abstract}

Keywords: Preschool Management Model, Structural Equation Modeling, Headmasters' Instructional Leadership, Mediator, Effective Teaching.

\section{Introduction}

In this study, the relationship between exogenous constructs such as instructional leadership, parental involvement in preschool education, preschool teachers' information and communication technology (ICT) in teaching, teacher professional development, and preschool development plans and endogenous construct, namely effective teaching among preschool teachers will be assessed through a Preschool Management Model (PMM), which has been designed by researcher guided by the theories of quality management in the field of education such as [1], [2], [3],[4] and previous studies [5]. The ecological theory can be applied in preschools to produce first class human capital that will lead and manage the future organization.

[6] states that the quality of preschool education plays a very important role in increasing the awareness of governments and parents to implement policies and programmes for preschools. With this, the emphasis on quality is seen as one of the most pragmatic approach to improving the performance of organizations in the field of education and academic achievement of students towards achieving Vision 2020. Preschools have to boost education quality excellence of the national education system that is relevant to meeting current demands and building capacity to meet the challenges ahead.

Quality of education is one of the important things in the Education Development Plan which emphasizes the quality of opportunity in education and excellence of educational institutions to determine the progress and prosperity of the country. Quality of education refers to development of human capital that is knowledgeable, skilled, and noble. Nevertheless, studies of previous preschools were less focused on the problem or pressure faced by preschool management systems, effective teaching, and the implementation of TQM in preschools [7] and implement effective school-based practice findings from developed countries [8] because the schools require strategies that are appropriate to the context, problems, and the needs of local development.

Issues that have existed in preschool education such as headmasters' instructional leadership, parental involvement in preschool education, teachers' ICT in teaching, professional development of teachers, preschool development plans and effective teaching that may affect the academic achievement of children are less addressed in Malaysia [9]. Therefore, it's time to conduct this research so that the quality of preschool education can be improved in the interests of the future children to overcome dropout in primary and secondary schools [10]. This assertion is supported by [11] who says that the quality of education can be improved if all parties involved such as the management, teachers, staff, and parents can jointly develop a new attitude that is focused on leadership, teamwork, collaborative practice, accountability, and recognition to ensure the children as future leaders will lead the country towards achieving international excellence and glory. Nevertheless, the responsibility of the school headmasters in the field of monitoring and supervision is very important to ensure the effectiveness of teaching and learning of children. Supervision is also an important aspect of evaluating the content and teaching methods in accordance with the requirements of the curriculum. 
In this study, the quality of preschool education will be reviewed based on the comprehensive Preschool Management Model in terms of effectiveness and school improvement which is the vision of the Ministry of Education for prioritizing key performance indicators (Key Performance Index, KPI) and National Key Result Areas (National Key Result Area, NKRA). The role of TQM principles in helping preschool classroom management as a method of improving the performance and the overall quality of the organization will be identified.

The results are expected to improve the quality of preschool education particularly in terms of academic excellence. Academic excellence is not only an important feature in the education management process which is increasingly important and challenging [13], but also coincides with the requirements of environmental factor in creating an effective learning organization in terms of systems thinking, personal mastery, mental models, shared vision, and learning team [14].

Preschool management model was tested with data based on instructional leadership of preschool headmasters, parental involvement in preschool education, preschool teachers' ICT in teaching, teachers' professional development, preschool development plans, and effective teaching for creating an effective preschool [15]. Teachers also have a personality or positive impact on their ability to manage schools more effectively [16] with the practices of headmasters' instructional leadership such as promoting the ideal, motivating and inspiring teachers and building intellectual stimulus.

The objectives of this study are as follows:

1. Identify whether instructional leadership of the headmasters affects effective teaching directly or indirectly.

2. Identify whether the involvement of parents in school education is a mediator of the relationship between headmasters' instructional leadership and effective teaching.

3. Identify whether preschool teachers' ICT in teaching is a mediator of the relationship between headmasters' instructional leadership and effective teaching.

4. Identify whether the teachers' professional development is a mediator of the relationship between headmasters' instructional leadership and effective teaching.

5. Identify whether the preschool development plan is a mediator of the relationship between headmasters' instructional leadership and effective teaching.

Based on the review of previous studies, the quality of the school depends on the model which has the criteria on a conceptual framework that can be used to answer the research questions. The overall conceptual framework for this study is shown in Figure 1 below:

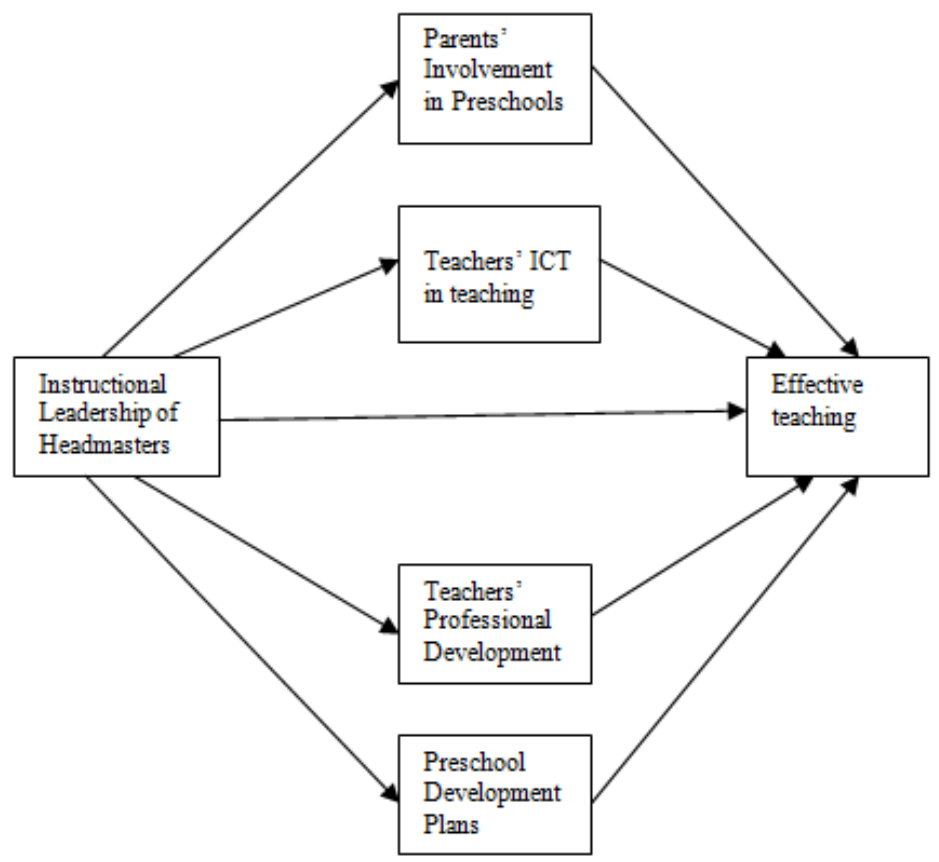

Figure 1 : Conceptual Framework Study

The conceptual framework study establishes the relationship between instructional leadership of the school headmasters, parents' involvement in preschool education, teachers' information and communication technology in teaching, professional development of preschool teachers, and preschool development plan for effective teaching in preschools. 
In this study, instructional leadership of preschool headmasters consists of all actions and activities carried out by a school leader to strengthen the teaching and learning process in preschools. The range of actions and activities is suggested by [17], but focus more on instructional leadership towards the contribution on aspects of children's learning. In this case, the quality of preschool education will be reviewed through a preschool management model that has been established to improve the quality of preschool in the present and in the future.

\section{Literature Review}

In order to achieve global excellence in education, many changes have taken place in the field of education in Malaysia. According to [18], it is natural that educational change will happen when there are rapid economical, social, political developments and the advent of information technology. Therefore, education system should prepare the younger generation to face the challenges of globalization, especially in the competitive pursuit of knowledge. This is because education is the main factor for the realization of national aspirations.

Instructional leadership of school headmasters plays an important role in providing education of the 21 st century. Studies on effective schools, the implementation of changes and improvements that have been run in various countries by researchers earlier form the basics of the concept of instructional leadership [19]. It thus has strengthened the belief among policy makers and policy practitioners that instructional leadership is a major factor that makes schools effective [19]. When changes occur in education, headmasters as instructional leaders in schools should encourage teachers to achieve success academically, work harder, and willing to put effort into implementing changes in schools. This shows that the instructional leader is a key factor for the success of the preschools and preschool achievement by taking into account the Child Protection Act, the Education Act, and the importance of preschool education curriculum.

[20] says that the instructional leadership role of the headmaster is considered important in driving schools towards effective school. [21] has been used as a guide to the study. According to him, the ecological theory assumes that individuals need to interact with a variety of environments. This theory has several stages of development.The stages in the ecological model of human development depends very much on how it is related to ecology. This theory also takes into account the qualities of relationship between the importance of surroundings which can influence children development.

In this study, it will be reviewed in terms of interaction, parenting practices, openness, acceptance, school assignments, learning facilities at home, open days, activities, and preschool programmes. This is supported by [21] who says that parents are the most active environmental agents since a child is born, and it can affect a child's development. According to [22], parents are involved not just in school, but also at home in their children's education. However, according to [23], time constraints make parents less sensitive to their role in the education of children and let their children learn without monitoring. The involvement of parents in the home and at school continuously correlated with academic achievement of children [24].

Preschool teachers' information and communication technologies in teaching refers to use of ICT in the early stages of children by exposing them to multimedia and computer. This encourages them to learn better, faster, and more efficient. Early childhood exposure to ICT can also help develop critical thinking, creativity, thus improving their skills [25].

In this study, preschool teachers' professional development is a process for individuals, groups, and organizations to acquire more efficient and effective teaching and learning. In addition, [26] says that it is a process that requires a long period of training involving theory as the basis of practice, codes of conduct of its own, and a high degree of autonomy so that the teaching profession can be labelled as a professional.

School development plan is an approach to organizing relevant information about the current state of preschool to the desired future state. It also allows teachers to set short-term and long-term goals and aspirations. Moreover, [27] says that the preschool development plan must be flexible and sensitive to the situation of local plans to improve the quality of preschool education.

According to [28], effective teaching refers to teachers who can bring children to the learning outcomes of the past and teachers not only know the concept, but also need to apply the concept or practices in classes taught. This involves a structured teaching pattern in terms of organization and conscious classroom lesson content to produce high quality education [29].

Social learning theory proposed by [30] emphasizes that a preschool teacher's behaviour is influenced by the environment through reinforcement and imitation learning, and the ways of preschool teachers' thinking can influence the quality of teaching in preschools. According to [30], observing and imitating the behaviour and attitudes of others is an act of learning. [30] theory also explains that human behaviour in the context of continuous reciprocal interaction between cognitive, behavioral, and environmental influences. 
The TQM philosophy was developed by [1] and [2]. According to [1], TQM can also be used in the field of education although it has been used successfully in business. TQM focuses on commitment to leadership and strong support from leaders in business in order to achieve quality awareness, involvement of all employees, continuous progress, and a systematic approach towards the success of the organization [31]. This opinion is supported by [32], which states that the school leaders should apply the ideas of TQM based on flexible, high commitment, and the government is targeting long-term strategy through customer satisfaction and confidence. In addition, [33] explains the ideas of TQM in education leadership, scientific methods and tools, problem solving, and organizational culture. [34] refers to the leadership in TQM that divides the work efficiency of individual leaders, shares ideas to give strong support [35] in order to work with teachers or administrators in achieving the organization's vision.

Based on the problems as discussed in research, the relationship between variable concept of instructional leadership of teachers, parental involvement in preschool education, preschool teachers' ICT in teaching, teachers' professional development, preschool development plans and effective teaching will be based on a model of a prior formation by researchers using conventional approaches SEM (Structural Equation Modeling).

\section{Method}

A pilot study was conducted in one hundred normal daily preschools to ensure that the questions in the questionnaire are well understood by respondents. Each preschool was represented by a preschool teacher. The selection of samples for respondents in the study was made randomly. This was done to evaluate the effectiveness of perceptions. The data were collected from 100 respondents in order to achieve the accuracy of the instrument as well as the reliability and validity of the instrument [36].

According to [37], Structural Equation Modeling (SEM) analysis method is designed to analyze quantitative data. SEM uses the test models for investigating the interrelationship of cause and effect between the variables in the study group. Model hypothesis proposed was used to test corresponding data collected from the survey respondents. In this study, SEM analysis was conducted using Analysis of Moment Structure (AMOS) version 23. In this research, Structural Equation Modeling (SEM) model with two-step approach proposed by [37] was used. According to [38], researchers should test the measurement model first, and if found fit to be accepted, then the researchers continue to test the structural model. Model structure is formed by correlating the measurement model.

Measurement model is part of the Structured Equation Modelling (SEM) which discusses the relationship between latent variables and variable observatories or each item. This is done to specify the relationshipbetween latent variables and each item [39]. When the measurement model has reached an acceptable overall fit, then the next step is to test the structural model. This test includes all structural path between the latent variables in the model and the overall fit of the hypothesized structural model.If the overall fit is unacceptable, then the model has to be modified based on the theory. [40] suggests categories fit in evaluating a model that has been built. Information about the kind of fit this category is summarized in the Table 1 as below:

Table 1 : The three categories of model fit and their levels of acceptance

\begin{tabular}{|c|c|c|}
\hline Name of category & Name of index & Lavel of acceptance \\
\hline 1. Absolute fit & $\begin{array}{l}\text { Chi-Square } \\
\text { RMSEA } \\
\text { GFI }\end{array}$ & $\begin{array}{l}\text { P-value }>0.05 \\
\text { RMSEA }<0.08 \\
\text { GFI }>0.90\end{array}$ \\
\hline Incremental fit & $\begin{array}{l}\text { AGFI } \\
\text { CFI } \\
\text { TLI } \\
\text { NFI }\end{array}$ & $\begin{array}{l}\text { AGFI }>0.90 \\
\text { CFI }>0.90 \\
\text { TLI }>0.90 \\
\text { NFI }>0.90\end{array}$ \\
\hline Parsimonious fit & Chisq/df & Chi-square/df $<3.0$ \\
\hline
\end{tabular}

This chapter discusses the methodology of the study.Hypotheses was tested by using the quantitative method. The study of the relationship between instructional leadership, involvement of parents in school education, teachers' ICT in teaching, teachers' professional development, the development plan and the effectiveness of teaching was carried out randomly on selected preschools. Primary data were collected using a questionnaire. Through research methodology described in this chapter, expected ways, methods, and approaches proposed are the most appropriate instrument to be used to achieve the objectives of this study. 


\section{Results}

Confirmatory Factor Analysis (CFA) is a special form of factor analysis. It is employed to test whether the measures of a construct are consistent with the researcher's understanding of the nature of the construct. The CFA procedure replaced the older methods to determine construct validity. Every measurement model of a latent construct needs to undergo CFA before modeling in SEM.

In this study, AMOS was run to calculate the standardized estimate and squared multiple correlations by clicking the respective box in the analysis menu. The standardized estimate indicates the factor loading for each item in a measurement model. Any item having loading less than 0.6 and $\mathrm{R}^{2}$ less than 0.4 should be deleted from the measurement model. An item having low factor loading simply means that particular item is deemed useless to measure that particular construct. Keeping useless item in a model will affect the fitness index of the model.

Reliability will assess through three criteria namely, internal reliability using Cronbach alpha with threshold 0.600 and above [41] calculated using SPSS. While construct reliability (CR) should be 0.6 and above and average variance extracted (AVE) should be greater than 0.5 using AMOS application. The result is shown in Table 2 as follows:

The goodness of fit indexes were obtained for each construct as shown in Table 2 below.

Table 2: Fit Indexes for the Constructs

\begin{tabular}{|l|l|l|l|l|l|}
\hline Contructs & $\begin{array}{l}\text { Absolute } \\
\text { fit } \\
\text { RMSEA } \\
(<0.08)\end{array}$ & $\begin{array}{l}\text { Increment } \\
\text { al fit } \\
\text { GFI } \\
(>0.90)\end{array}$ & $\begin{array}{l}\text { Parsimonio } \\
\text { us fit } \\
\text { CFI } \\
(>0.90)\end{array}$ & $\begin{array}{l}\text { Chi } \\
\text { Square /df } \\
(<5.0)\end{array}$ & \\
\hline KI & .073 & .991 & .996 & 2.410 & Achieved \\
\hline PIB & .000 & .998 & 1.00 & 0.483 & Achieved \\
\hline TMK & .006 & .992 & .995 & 2.228 & Achieved \\
\hline PPG & .076 & .991 & .992 & 2.544 & Achieved \\
\hline PPP & .043 & .995 & .997 & 1.497 & Achieved \\
\hline PB & .079 & .996 & 1.00 & 1.015 & Achieved \\
\hline
\end{tabular}

After each construct had achieved goodness of fit index, then the structural model was drawn based on the result of measurement model. This structural model is shown in Figure 2.

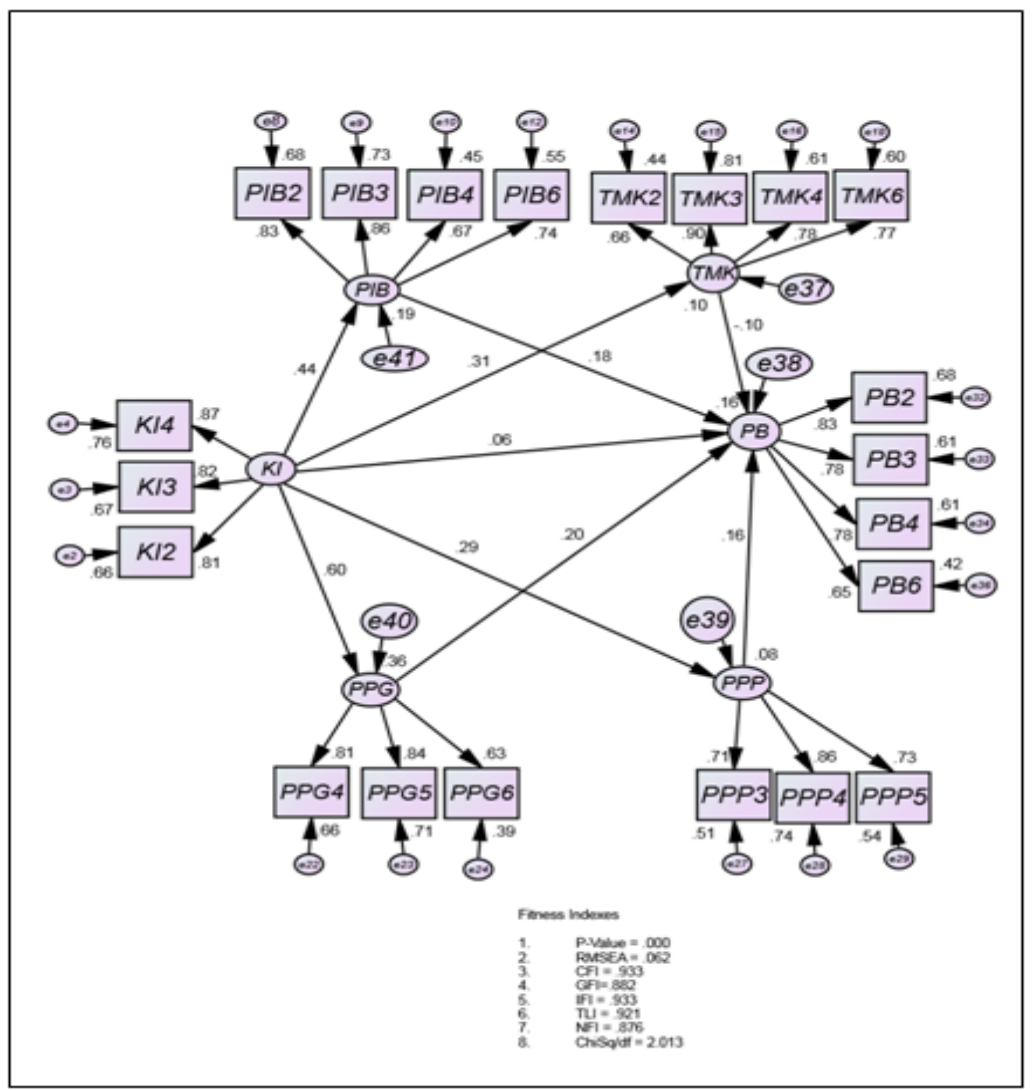

Figure 2 : The constructs are assembled into Structural Model for path analysis 
Analyzing the mediator in this model:

i) Identify whether instructional leadership of the headmasters' affects effective teaching directly or indirectly.

Table 3 : The direct effect of headmaster' instructional leadership on effective teaching is significant (Beta Coefficient 0.27)

\begin{tabular}{|l|l|l|c|c|c|c|c|}
\hline Construct & Path & Construct & Estimate & $\begin{array}{l}\text { Standardized } \\
\text { Estimate }\end{array}$ & C. R. & P-Value & Result \\
\hline $\begin{array}{l}\text { Effective } \\
\text { Teaching }\end{array}$ & $\longleftarrow$ & $\begin{array}{l}\text { Headmasters' } \\
\text { Instructional } \\
\text { Leadership }\end{array}$ & 0.27 & 0.39 & 3.779 & 0.001 & Significant \\
\hline
\end{tabular}

The output in Table 3 shows beta coefficient (B1) is 0.27 and it has a significant effect on effective teaching ( $\mathrm{p}$-value $<0.001$ ). In this study, the direct and indirect effect of independent variable on dependent variable will be examined.

ii) Identify whether the involvement of parents preschool education is the mediator of the relationship between headmasters' instructional leadership and effective teaching.

Table 4: The standardized regression weights and its significant for each path

\begin{tabular}{|l|c|l|c|l|l|}
\hline Construct & Path & Construct & $\begin{array}{l}\text { Standardized } \\
\text { Estimate }\end{array}$ & P-Value & Result \\
\hline $\begin{array}{l}\text { Involvement of parents in } \\
\text { preschool education }\end{array}$ & $\leftarrow$ & $\begin{array}{l}\text { Headmasters } \\
\text { Leadership }\end{array}$ & 0.44 & 0.001 \\
\hline Effective Teaching & $\leftarrow$ & $\begin{array}{l}\text { Involvement of parents in } \\
\text { preschool education }\end{array}$ & 0.18 & 0.020 & Significant \\
\hline Effective Teaching & $\longleftarrow$ & $\begin{array}{l}\text { Headmasters Instructional } \\
\text { Leadership }\end{array}$ & 0.06 & 0.548 & Not \\
\end{tabular}

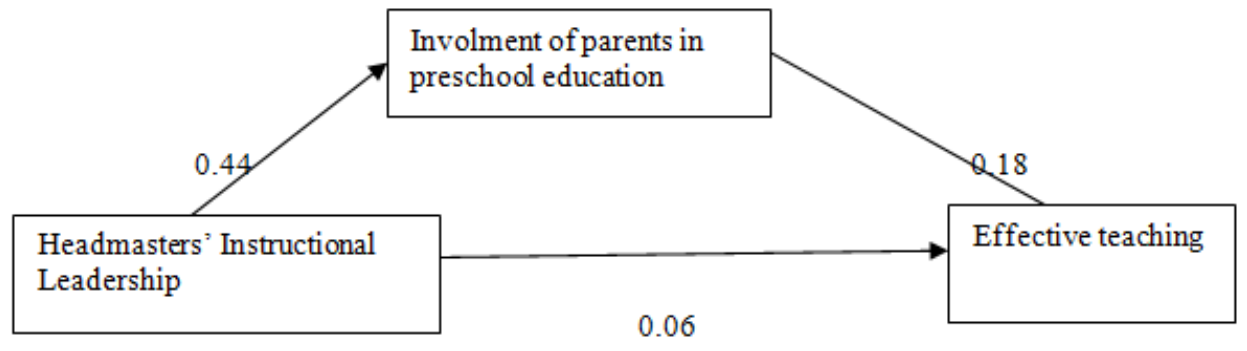

1) The Indirect Effect $=0.44 \times 0.18=0.0792$

2) The Direct Effect $=0.06$

3) Since Indirect Effect $>$ Direct Effect, the mediation occurs

So, involvement of parents in preschool education is a full mediator.

Figure 3 : The procedure for testing involvement of parents in preschool education as a mediator

Table 5 : The results of Mediation Test (PIB)

\begin{tabular}{|l|l|l|l|}
\hline \multicolumn{1}{|c|}{ Hypothesis Statement for Path Analysis } & Estimate & P-Value & Result \\
\hline $\begin{array}{l}\text { Ha1: Headmaster' Instructional Leadership has significant effect } \\
\text { on Involment of parents in preschool education }\end{array}$ & 0.44 & 0.001 & Supported \\
\hline $\begin{array}{l}\text { Ha2: Involment of parents in preschool education has significant } \\
\text { effect on effective teaching }\end{array}$ & 0.18 & 0.042 & Supported \\
\hline $\begin{array}{l}\text { Ha3: Headmaster' Instructional Leadership has significant effect } \\
\text { on effective teaching }\end{array}$ & 0.06 & 0.548 & Not Supported \\
\hline
\end{tabular}


Conclusion : Involvement of parents in preschool education is a mediating variable in the relationship between headmasters' leadership and effective teaching. The output in Table 5 shows the beta coefficient (B1) is reduced from 0.27 to 0.06 when involvement of parents in preschool education enters this model and the direct effect of B1 on effective teaching is no longer significant ( $\mathrm{p}$-value $=0.548)$. Then the mediation is called complete mediation.

iii) Identify whether preschool teachers' ICT in teaching is the mediator of the relationship between headmasters' instructional leadership and effective teaching.

Table 6 : The standardized regression weights and its significant for each path

\begin{tabular}{|l|l|l|c|l|l|}
\hline Construct & Path & Construct & $\begin{array}{l}\text { Standardized } \\
\text { Estimate }\end{array}$ & P-Value & Result \\
\hline $\begin{array}{l}\text { Preschool teachers' ICT in } \\
\text { teaching }\end{array}$ & $\longleftarrow$ & $\begin{array}{l}\text { Headmasters' } \\
\text { Instructional Leadership }\end{array}$ & 0.065 & 0.001 & Significant \\
\hline Effective Teaching & $\longleftarrow \begin{array}{l}\text { Preschool teachers' ICT } \\
\text { in teaching }\end{array}$ & 0.042 & 0.167 & $\begin{array}{l}\text { Not } \\
\text { Significant }\end{array}$ \\
\hline Effective Teaching & $\longleftarrow$ & $\begin{array}{l}\text { Headmasters' } \\
\text { Instructional Leadership }\end{array}$ & 0.057 & 0.548 & $\begin{array}{l}\text { Not } \\
\text { Significant }\end{array}$ \\
\hline
\end{tabular}

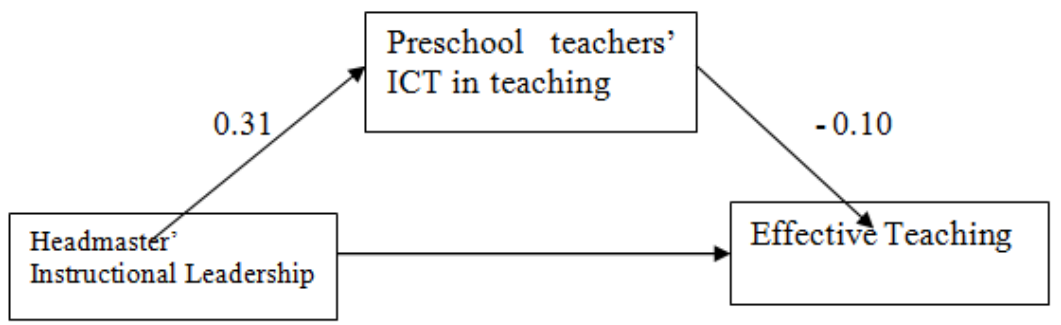

0.06

1) The Indirect Effect $=0.31 \times-0.10=-0.031$

2) The Direct Effect $=0.06$

3) Since, indirect effect $<$ direct effect, no mediation occurs

So, preschool teachers' ICT in teaching is not a mediator in this study.

Figure 4 : The procedure for testing teacher professional development as a mediator

Table 7: The results of Mediation Test (ICT)

\begin{tabular}{|l|l|l|l|}
\hline Hypothesis Statement for Path Analysis & Estimate & P-Value & Results on Hypothesis \\
\hline $\begin{array}{l}\text { Hb1: Headmaster' Instructional Leadership has significant } \\
\text { effect on preschool teachers' ICT in teaching }\end{array}$ & 0.065 & 0.001 & Supported \\
\hline $\begin{array}{l}\text { Hb2: Preschool teachers' ICT in teaching has significant effect } \\
\text { on effective teaching }\end{array}$ & 0.042 & 0.167 & Not Supported \\
\hline $\begin{array}{l}\text { Hb3: Headmaster' Instructional Leadership has significant } \\
\text { effect on effective teaching }\end{array}$ & 0.057 & 0.548 & Not Supported \\
\hline
\end{tabular}

Conclusion: Preschool teachers' ICT in teaching is not a mediating variable in the Relationship between headmaster' leadership and effective teaching. The output in Table 5 shows that p-value for $\mathrm{Hb} 2$ is 0.167 and that for $\mathrm{Hb} 3$ is 0.548 . Then preschools'ICT in teaching is not a mediator in this model because it has no significant effect on effective teaching.

iv) Identify whether the teacher professional development is a mediator of the relationship between headmasters' instructional leadership and effective teaching. 
Table 8 : The standardized regression weights and its significant for each path

\begin{tabular}{|l|l|l|c|l|l|}
\hline Construct & Path & Construct & $\begin{array}{l}\text { Standardized } \\
\text { Estimate }\end{array}$ & P-Value & Result \\
\hline $\begin{array}{l}\text { Teacher professional } \\
\text { development }\end{array}$ & $\leftarrow$ & $\begin{array}{l}\text { Headmaster' } \\
\text { Instructional Leadership }\end{array}$ & 0.60 & 0.001 & Significant \\
\hline Effective Teaching professional & $\begin{array}{l}\text { Teacher } \\
\text { development }\end{array}$ & 0.20 & 0.032 & Significant \\
\hline Effective Teaching & $\leftarrow$ & $\begin{array}{l}\text { Headmasters' } \\
\text { Instructional Leadership }\end{array}$ & 0.06 & $\begin{array}{l}\text { Not } \\
\text { Significant }\end{array}$ \\
\hline
\end{tabular}

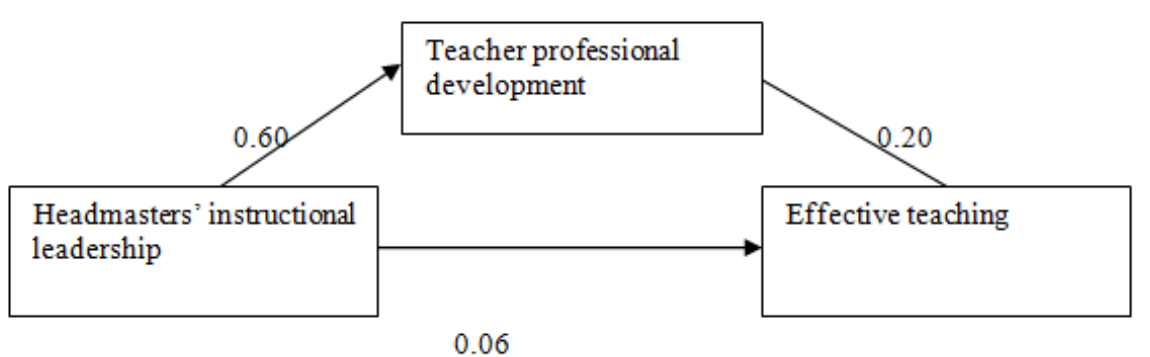

1) The Indirect Effect $=0.60 \times 0.20=0.12$

2) The Direct Effect $=0.06$

3) Since Indirect Effect $>$ Direct Effect, the mediation occurs

So, teacher professional development is a full mediator in this study.

Figure 5 : The procedure for testing teacher professional development as a mediator

Table 9 : The results of Mediation Test (PPG)

\begin{tabular}{|l|c|c|c|}
\hline Hypothesis Statement for Path Analysis & Estimate & P-Value & Results on Hypothesis \\
\hline $\begin{array}{l}\text { Hc1: Headmasters' Instructional Leadership has significant } \\
\text { effect on Teacher professional development }\end{array}$ & 0.60 & 0.001 & Supported \\
\hline $\begin{array}{l}\text { Hc2: Teacher professional development has significant } \\
\text { effect on effective teaching }\end{array}$ & 0.20 & 0.032 & Supported \\
\hline $\begin{array}{l}\text { Hc3: Headmasters' Instructional Leadership has significant } \\
\text { effect on effective teaching }\end{array}$ & 0.06 & 0.001 & Not Supported \\
\hline
\end{tabular}

Conclusion : Teacher professional development is a mediating variable in the relationship between headmasters' leadership and effective teaching. The output in Table 8 shows the beta coefficient (B1) is reduced from 0.27 to 0.06 when teachers' professional development enters this model and the direct effect of $\mathrm{B} 1$ on effective teaching is no longer significant $(\mathrm{p}$-value $=0.548)$. Then the mediation is called complete mediation.

v) Identify whether the preschool development plan is a mediator of the relationship between headmasters' instructional leadership and effective teaching.

Table 10 : The standardized regression weights and its significant for each path

\begin{tabular}{|l|l|l|c|l|l|}
\hline Construct & Path & Construct & $\begin{array}{l}\text { Standardized } \\
\text { Estimate }\end{array}$ & P-Value & Result \\
\hline Preschool development plan & $\longleftarrow$ & $\begin{array}{l}\text { Headmasters Instructional } \\
\text { Leadership }\end{array}$ & 0.29 & 0.001 & Significant \\
\hline Effective Teaching & $\longleftarrow$ & Preschool development plan & 0.16 & 0.032 & Significant \\
\hline Effective Teaching & $\longleftarrow$ & $\begin{array}{l}\text { Headmasters Instructional } \\
\text { Leadership }\end{array}$ & 0.06 & 0.548 & $\begin{array}{l}\text { Not } \\
\text { Significant }\end{array}$ \\
\hline
\end{tabular}




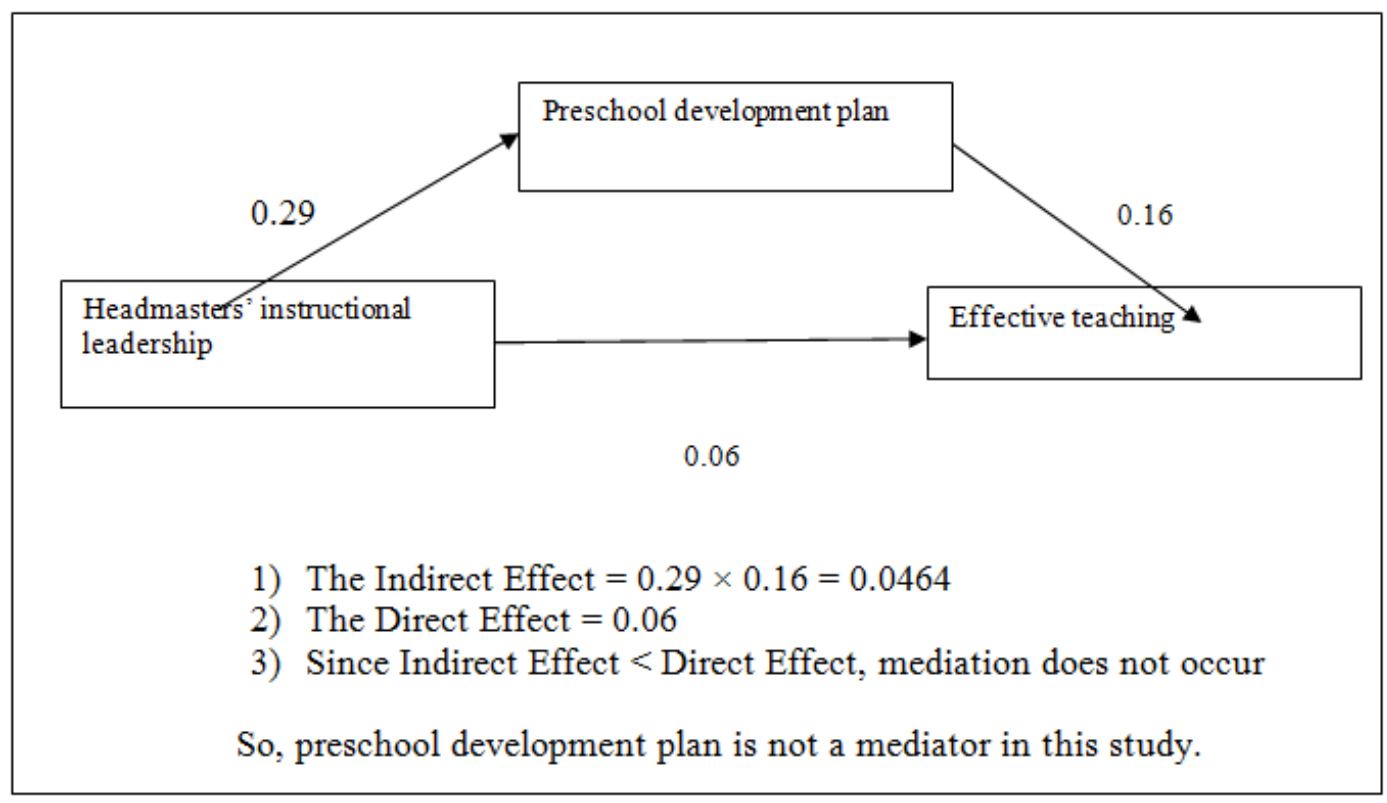

Figure 6: The procedure for testing preschool development plan as a mediator

Table 11 : The results of Mediation Test (PPP)

\begin{tabular}{|l|c|c|l|}
\hline Hypothesis Statement for Path Analysis & Estimate & P-Value & Results on Hypothesis \\
\hline $\begin{array}{l}\text { Hd1: Headmasters' Instructional Leadership has significant effect } \\
\text { on preschool development plan }\end{array}$ & 0.29 & 0.001 & Supported \\
\hline $\begin{array}{l}\text { Hd2: Preschool development plan has significant effect on } \\
\text { effective teaching }\end{array}$ & 0.16 & 0.032 & Supported \\
\hline $\begin{array}{l}\text { Hd3: Headmasters' Instructional Leadership has significant effect } \\
\text { on effective teaching }\end{array}$ & 0.06 & 0.548 & Not Supported \\
\hline
\end{tabular}

Conclusion : Preschool development plan is a mediating variable in the relationship between headmasters' leadership and effective teaching. The output in Table 11 shows the beta coefficient (B1) is reduced from 0.27 to 0.06 when preschool development plan enters this model and the direct effect of B1 on effective teaching is no longer significant ( $\mathrm{p}$-value $=0.548$ ). Then the mediation is called complete mediation.

\section{Discussion and Conclusion}

The efficiency and success of the organization, especially the top preschools, mean the extensive involvement of all parties. In this case, the role of the headmaster is very important in moving the work culture of quality to all school staff. The top management should apply TQM concept in preschool so that the information can be distributed to all teachers effectively to improve the quality of preschool education.The findings show that parents' involvement in preschool, teachers' professional development and preschool plan are mediators that highly contribute to quality of the relation between instructional leadership of headmasters and effective teaching. However, headmasters' instructional leadership should fully implement TQM practices that will improve the quality of preschool education system in Sarawak.

\section{References}

[1]. Deming, W. E. (1986). Out of the crisis. Massachusetts : MIT Center Advanced Engineering Study.

[2]. Juran, J. M. (1989). Juran on leadership for quality. An executive handbook. New York: The Free Press.

[3]. Crosby, P. B. (1986). Quality without tears: The Art of Hasslle-free Management. Singapore : McGraw-Hill.

[4]. Oakland, J.S. (2003). Total Quality Management: Text with cases (third edition). London: Elsevier.

[5]. Suntonrapo, D., Auyporn, R., \& Thaweewat, P. (2009). An investigation of the effects between academic self-concept, nonacademic self concept and academic acievement. Causal ordering models Research in Higher Education Journal 2.

[6]. Miquela Rivera. (2008). The Hispanic Outlook in Higher Education, 18.

[7]. Jean, C. dan Karen, S. (2012). Principals' Perceptions of the use of Total Quality Management Concepts for School Improvement in Mauritius: Leading or Misleading? The International Journal of Learnin,. Vol.18 (4).

[8]. Evertson, C. M. dan Poole, I. R. (2008). Proactive Classroom Management : 21 st Century Education. Vanderbilt University.

[9]. Shahril Marzuki. (1997). Kajian sekolah berkesan di Malaysia. Model lima faktor, Universiti Kebangsaan Malaysia.

[10]. Carpenter, D. M., \& Ramirez, A. I. (2007). More than one gap: Dropout rate gaps between and among Black, Hispanic and White students. Journal of Advanced Academic, 19(1).

[11]. Peterson, E. R., Rubin-Davies, C. M., Elley-Brown, M. J., Widdowson, D. A., Dixon. R. S, \& Irving, E. S. (2011) . Who is to Blame? Students, Teachers and parents view on who is responsible for student Achievement. Research in Education, 86(1).

[12]. Robinson, M. J., Lloyd, C. A., dan Rowe, K. J. (2008). The impact of Leadership on Student Outcomes: An Analysis of the Different Effects of Leadership Types. Educational Administration Quarterly, Vol.44(5). 
[13]. Regina M. Oliver, Joseph H. Wehby, Daniel J. Reschly. (2011). Teacher classroom management practices : Effects on disruptive or aggressive student behavior. Campbell systematic Review, 2011: 4 academic involvement: Consequences on chievement goals, European Journal of Psychology of Education, 24(2).

[14]. Sanja, T. V. (2012). The Significance of Preschool Teacher's Personality in Early Childhood Education: Analysis of Eysenck's and Big Five Dimensions of Personality. International Journal of Psychology and Behavioral Sciences. 2(2).

[15]. Shahril @ Charil Hj. Marzuki \& Muhammad Faizal A. Ghani. (2007). Pembentukan model sekolah berkesan Malaysia: Satu kajian Dephi. Journal Pendidikan, 27(1).

[16]. Retna, K. S. (2011). The relevance of personal mastery to leadership. The case of school principals in Singapore, school leadership and management $31(5)$.

[17]. Starr, K. and Oakley. (2008). Teachers leading learning: The role of principals. The Australian Educational Leader, 30(4).

[18]. [18] Jita, L. C. (2010). Instructional leadership for the improvement of science and mathematics in South Africa. Procedia Social and Behavioral Sciences, Vol.9(1).

[19]. Hallinger, P. (2003). Leading education change: reflection on the practice of instructional and transformational leadership. Cambridge Journal of Education, 33(3).

[20]. Buckner, K. R. (2011). Leadership practices of female principals. Capella University.

[21]. Bronfenbrenner, U. (1989). Ecological systems theory. Annals of child Development, Vol.6.

[22]. Ahmet, C. S. (2012). The contributionof School-Family Cooperation on Effective Classroom Management in Early Childhood Education. Educational Sciences: Theory \& Practice.

[23]. Lee, J. \& Green, K. (2008). Hmong parental involvement and support : A comparison between families of high and low achieving high school Seniors. Hmong Studies Journal, 9(1).

[24]. Marzano, R. J. (2011). Classroom Management: Whose job is it? Educational Leadership, 69(2).

[25]. Ruslin Amir, Norzaini Azman \& Ibrahim Komoo. (2010). Kesedaran, Kefahaman dan Nilai Sepunya Pelajar dan Guru: Sumbangan kepada Pendidikan Awal Langkawi Geopark. Akademika 80.

[26]. Muijs, D. dan Reynolds, D. (2011). Effective teaching: evidence and practice. London Sage.

[27]. Crandall, D. P., Eiseman, J. W., \& Seashore, K. (1986). Strategic planning issues that bear the success of school improvement efforts. Education Adminitration Querterly, Vol 22.

[28]. Brown, N., Morehead, P. \& Smith, J. (2008). But i love children : Changing elementary teacher candidates' conceptions of qualities of effective teacher. Teacher Education Quartely, 35(1)

[29]. Schussler, D. (2009). Beyond content: How teacher manage classroom to facilitate intellectual engagement for disengaged student. Theory Into Practice, 48(2).

[30]. Bandura, A. (1989). Social cognitive theory. In R. Vasta (Ed.), Annals of child development. 6(1), 1-60. Six theories of child development. Greenwich, CT: JAI Press.

[31]. Mukhopadhyay, M. (2005). Total Quality Management in Education (second edition). New Delhi: Sag

[32]. Leithwood, K., \& Levin, B. (2010). Understanding how leadership influences student learning. International Encyclopedia od education. Oxford, UK: Elsevier.

[33]. De Jager dan Nieuwenhuis. (2005). Linkages Between Total Quality Management and the Outcomes-based Approach in an Education Environment. Quality in higher Education, Vol.11(3).

[34]. Printy, S. M. (2010). Principals' influence on instructional quality: insights from us school. School leadership and management, $30(2)$.

[35]. Raminah Haji Ahmad. (2005). Kepengetuaan dan kepimpinan sekolah: Pembangunan dan penambahbaikan pengajaran. Jurnal Pemimpin, Vol5 (1).

[36]. Krejcie, R. V., \& Morgan, D. W. (1970). Determining sample size for research activities. Educational and Psychological Measurement, 30, 607-610.

[37]. Chua, Y. P. (2014). Asas statistik penyelidikan. Shah Alam : McGraw- Hill Education.

[38]. Kline, R. B. (2005). Principles and practice of structural equation modeling. USA: The Guilford Press.

[39]. Byrne, B. M. (2010). Structural equation modeling wtih AMOS, second edition. NJ:Lawrence Erlbaum Association, Inc

[40]. Kyriakides, L., Creemers B., Antoniou, P. \& Demetriou, D. (2010). A synthesis of study searching for school factors: Implications for theory and research British Educational Research Journal, 36(5).

[41]. Zainudin, A. (2010). Research Methodology for Business and Social Science. Shah Alam: Universiti Teknologi MARA Publication Centre. (UPENA). 